\title{
Review
}

\section{The republic of the living: Biopolitics and the critique of civil society}

\author{
Miguel Vatter \\ Fordham University Press, New York, 2014, 403pp., ISBN: 978-0823256020 \\ Contemporary Political Theory (2016) 15, e42-e45. doi:10.1057/cpt.2015.30; \\ published online 9 June 2015
}

In the The Republic of the Living, Miguel Vatter offers an original and provocative intervention into the burgeoning field of biopolitical theory. Vatter's book is erudite, and wide-ranging, stretching form an examination of Greek tragedy in Hegel's account of civil society, through to critical engagements with contemporary biopolitical theorists, including Antonio Negri, Giorgio Agamben and Roberto Esposito. What is truly impressive about The Republic of the Living is that it forces a rethinking of received interpretations and positions in both the debate over biopolitics and the history of political thought. The Republic of the Living is a work of political theory in the best sense, which draws on the tradition of political thought in the interest of creating what, following György Lukács, Vatter terms 'the birth of the new' (p. 309).

The book's title, The Republic of the Living, references its two key commitments: to republicanism and to an 'affirmative' biopolitics. Taken together, these two central commitments motivate a shift of perspective away from the state and sovereignty to the sphere of civil society, and the production, reproduction and normalization of life in the family, the economy and the realm of natural rights. This shift allows Vatter to develop an intriguing and important account of the contemporary relation of politics to life. In opposition to the liberal assumption that less politics equals less government and, hence, more freedom, Vatter highlights those forms of government that operate in and through civil society. Freedom, he argues, may require not less politics, but more, in order to politicize those relations of dependence that typify the economy, the workplace and the family.

Vatter's republicanism leads him to criticize the antinomianism of much biopolitical thought. Against Agamben's contention that law necessarily abandons 'bare life', Vatter argues that only 'an internal and affirmative relationship between law and life' will be sufficient to overcoming the normalizing powers of liberal civil society (p. 11). One of the key strengths of the book is its willingness to confront the extent of the challenge that the biopolitical normalization of life poses for any

() 2016 Macmillan Publishers Ltd. 1470-8914 Contemporary Political Theory Vol. 15, 2, e42-e45 
republican politics. The book is animated by the question of whether this challenge is an overwhelming one, or whether, on the contrary, a 'republic of the living' remains possible. While Vatter's own political commitments are clearly republican, this book is not a nostalgic attempt to revive neo-Roman political concepts, oblivious to the extent to which contemporary capitalism has destabilized their terms of reference. Rather, Vatter brings Karl Marx's thought into relation with biopolitical theory in order to provide a new account of economic government that breaks with certain key tenets of much contemporary 'economic theology'. What makes Vatter's an important and novel contribution to the growing debate over economic theology is that it is located firmly on the terrain of contemporary capitalism, and not on the ahistorical plane of an 'economy' that can be traced back to Periclean Athens.

Vatter distinguishes his own approach from that of the 'economic theology' of a diverse group of thinkers, including Charles Taylor, Max Weber and Agamben, by critically engaging with two axioms that he sees as central to economic theology: first, the interpretation of Adam Smith's account of the 'invisible hand' as a secularized providential paradigm, and second, its designation of credit, rather than exchange, as the form of value of contemporary capital. Taken together, Vatter argues, these axioms produce an economic theodicy as the economy becomes the 'final tribunal of divine justice' (p. 291). Vatter suggests that this approach not only obscures the scientific basis of modern economics, but also, in stressing the centrality of credit, faith and confidence to contemporary market relations, fails to grasp the continuing centrality of the exchange relation between formally equal juridical persons. In analyzing the value form of contemporary capitalism, Vatter offers an important corrective to the obfuscation of the classical political economists, who, as Wood (2000, p. 19) has noted, 'discovered the 'economy' in the abstract and began emptying capitalism of its social and political content'.

Yet Vatter risks obscuring the novelty of Marx's non-theological account of the dynamics of the capitalist economy when he repeats Foucault's (2008, p. 282) claim that 'economics is a discipline without God'. Here, it is worth recalling that Foucault made this remark in the context of a discussion of the Scottish Enlightenment thinkers Smith and Adam Ferguson, both of whom drew heavily from providential accounts of the natural order in formulating their critiques of economic and social planning. This perhaps explains why, when Vatter turns to Friedrich Hayek, who drew heavily on the social theory of the Scots, he rightly notes that governmentality conducts us into dependence on a spontaneous order that we are unable to master or comprehend 'as if it were a secularized version of divine providence' (p. 209). For Vatter, however, Hayek cannot easily fit into the account of secularized providence, as the Austrian economist resolves the problem of coordinating actions in a spontaneous order through a double appeal to law as nomos, and to cybernetics and evolutionary biology.

However, this picture is complicated if we consider Hayek's own suggestion that his theory of spontaneous social order is borrowed not from biology, but from the 
evolutionary social theory of thinkers like Smith and Ferguson (Hayek, 2011, p. 116). It is by secularizing these earlier thinkers that Hayek produces an account of social evolution that necessitates blind submission to the incomprehensible forces of the market. Contra Foucault, economics is not a discipline without God, but Vatter is not doing economics, and neither was Marx. Rather, both of them are engaged in the 'critique of political economy', and it is this critique, and not economics, with its eternal laws and incomprehensible imperatives, that is truly a science without God, and is thus capable of historicizing capitalism and revealing both its contingency and its distinctive forms of compulsion.

In highlighting the specificity of capitalism, Vatter helps to undo theological accounts of the economy. And yet, when he comes to outlining his own affirmative biopolitics, he wants to hold on to a conception of living labour that is simultaneously 'life' and 'God'. Turning to Baruch de Spinoza's suggestion that 'those speak best who call God "life", Vatter develops a providential account of 'eternal life', in which God favours those who struggle to expand their own powers. God is central also to Vatter's brilliant re-reading of Hannah Arendt's account of 'natality', which he depicts as the condition of human freedom, which is itself conditioned by an act of divine creation. It is this created life that is central to the affirmative thrust of Vatter's critique of civil society. There is 'something irreducibly affirmative about the concept of the power of life', he argues, which necessitates that we free the theory of biopolitics from its association with a power of death (p. 264). Vatter's affirmative biopolitics draws not only on Spinoza and Arendt, but also on Nietzsche and Marx. In the latter case, Vatter provides a biopolitical re-reading of Marx's controversial contention that the social relations of capitalism ultimately become a fetter on the development of the forces of production. For Vatter, living labour appears as the barrier to the continuing expansion of capitalism, as capital both impoverishes those who labour, in what Marx calls a process of 'pauperization', and faces the antagonism of that vital power it seeks to subordinate.

In order to uphold 'life' itself as the antagonistic power that exceeds the capitalist social relation, Vatter draws on Foucault's suggestion that 'life' constantly escapes the technologies that seek to govern it. Tempering the exuberance about this antagonistic power of life that is found in the work of Negri, Vatter also suggests that capital has been able to manage the life that threatens to become its fetter by way of those political technologies Foucault referred to as 'police', which sought to augment the vital force of the state. Capital, as Vatter portrays it, is a 'metabolic, living process' and in subsuming living labour, it is the 'upside-down mirror of human self-creation' (p. 87). As Noys (2011, p. 15) has suggested, however, it may be that 'the mirror of vitalism' works the other way around as contemporary vitalist theory 'mirrors capitalism's own fantasy of an always excessive, always on-tap, force of life underpinning its operation and from which value can always be extracted'.

Turning to Lukács, Vatter depicts capitalism as a conflict between the temporality of the capitalist, who wants only to accumulate abstract surplus time, and the time of 
the worker, for which the time of wage labour is felt as an imposition on the time of life. In temporalizing class conflict, Vatter suggests that Lukács casts off the myth that the labour contract is eternally valid, and dissolves the 'social facts' of capitalism into processes. Citing Lukács, however, Vatter notes of these processes, that, 'if their Being appears as a Becoming, this should not be construed as an abstract universal flux sweeping past' but as the production and reproduction of social relations (p. 306). Yet Lukács' critique of those theories of becoming that reveal, beneath the flow, an unchanging essence, is not easily reconciled with the contention that guides Vatter's affirmative vitalism: 'From the perspective of God as absolute substance, or immanence, life is power and power is life' (p. 267).

Lukács' critique would also seem to call into question the passage from Löwith that Vatter cites in order to develop an affirmative biopolitics of 'eternal life' that he thinks through the Nietzschean lens of the eternal return: 'The eternal recurrence is a recurrence of what is always the same, that is: of life that is uniform and of equal power in everything living' (p. 324). Such an account recalls Walter Benjamin's suggestion that eternal recurrence is the temporality of monotonous commodity relations, equivalent to the punishment assigned to children who must stay behind to write lines. To break with this monotonous repetition may require more than faith in the excessive, creative powers of life. Rather, just as Marx overcame his early Feuerbachian metaphysics by historicizing the category of labour, contemporary biopolitical theory may need to historicize life - and its own fascination with it. In situating his intervention in the context of the real subsumption of life to capital, Vatter takes a key step in that direction: to complete this path may require a thought for which 'life' is no more eternal than capitalism.

\section{References}

Foucault, M. (2008) The Birth of Biopolitics. New York: Palgrave Macmillan.

Hayek, F. von (2011) The Constitution of Liberty. Chicago, IL: University of Chicago Press.

Noys, B. (2011) The poverty of Vitalism (and the Vitalism of Poverty). Paper presented at To Have Done with Life: Vitalism and Anti-vitalism in Contemporary Philosophy Conference; 17-19 June, MaMa, Zagreb, Croatia, https://www.academia.edu/689255/The_Poverty_of_Vitalism_and_the_Vitalism_of_ Poverty_,accessed 27 April 2015.

Wood, E.-M. (2000) Democracy against Capitalism: Renewing Historical Materialism. Cambridge: Cambridge University Press.

Jessica Whyte

University of Western Sydney, Penrith NSW 2751, Australia j.whyte@uws.edu.au 